\title{
Effects of a single comective exercise and taping on gait pattems, plantar pressure, balance, and pain in female moderate hallux valgus patients
}

\author{
Tae-Geun Yoo, Hyun-Seok Cho, \& Man-Gyoon Lee* \\ Kyung Hee University
}

\begin{abstract}
[Purpose] This study was designed to examine the effects of a single corrective exercise (CEX) and corrective kinesio taping (CKT) on gait patterns, plantar pressure, balance, and pain in 20 30s female patients with moderate hallux valgus. [Methods] Twenty-one participants (age: 30.1 \pm 5.1 yrs; height: $164.1 \pm 4.8 \mathrm{~cm}$; body weight: $56.7 \pm 6.8 \mathrm{~kg}$; body mass index: $21.2 \pm 5.7 \mathrm{~kg} \cdot \mathrm{m}^{-2}$; hallux valgus angle: $27.2 \pm 6.1^{\circ}$ ) with hallux valgus was recruited and participated in three trials, i.e., CEX trial, CKT trial, and combined CEX and CKT $(C E X+C K T)$ trial, repeatedly in a counter-balanced order. One week of wash-out period was placed between the trials to minimize the effect of the previous treatment on the next treatment. Variables related to gait pattern, plantar pressure, balance, and pain were measured during each treatment. We carried out repeated two way ANOVA on measured variables. [Results] 1) Regarding gait patterns, CEX treatment and CEX+CKT treatments showed significant increases in the length of patients strides, the single support line during the stance phase, and significant reduction of the cadence. 2) Regarding gait cycle, CEX treatment and CEX+CKT treatments showed significant reductions in the contact times of forefoot, midfoot, and heel. There was a significant reduction of double stance phase in CEX treatment. 3) Regarding foot pressure on gait, CEX+CKT treatments significantly increased the maximum pressure of midfoot and heel. CEX treatments significantly increased the maximum pressure of forefoot. 4) Regarding balance, CEX treatment and CKT treatments significantly increased one leg standing with eyes closed. 5) Pain was significantly reduced in CKT treatment and CEX+CKT treatments. [Conclusion] According to the aforementioned results, it was concluded that a single CKT treatment was effective in reducing pain when walking and that plantar pressure, gait pattern, gait cycle, and balance were improved through a single bout of CEX treatments. Therefore, treatments by stage, starting with CKT treatments to reduce the pain, and then treating CEX to improve the gait pattern, gait cycle, foot pressure when walking, and balance ability, would be effective. Future research is warranted to identify the effects of long-term treatments.
\end{abstract}

Key words: corrective exercise, kinesio taping, hallux vagus, gait pattern, plantar pressure

논문 투고일 : 2020. 03. 20.

논문 수정일 : 2020. 04. 19.

게재 확정일 : 2020. 05. 11.

* 교신저자 : 이만균(mlee@khu.ac.kr).

\begin{abstract}
서 론
무지외반증(hallux valgus)은 1871년 Carl Heuter 에 의해 처음 제시된 발의 앞부분에서 볼 수 있는 가장 흔 한 만성 질환으로서, 무지외반증의 외형적 특징은 첫 번 째 중족골(first metatarsal bone)에서 이어지는 첫 번째
\end{abstract}


근위 지절골(first proximal phalanx bone)에 해당하는 엄지발가락이 바깥쪽으로 벌어지는 것이며, 첫 번째 중족 골의 원위부(distal part)가 발 안쪽으로 두드러지게 튀 어나오면서 통증이 발생한다(Vanore et al., 2003). 무 지외반증은 18 65세에서 $23 \%$ 의 유병률을 보이며, 이 는 성인 5 명 중 1 명에 해당되는 높은 수치이다( Nix et al., 2010). 국내의 경우 무지외반증 환자가 2005년 2만 명에서 2013년 5만 6천명으로 280\% 증가되었으며, 여 성의 발병률이 남성에 비해 5.5 배 더 높다고 보고되었다 (Health Insurance Review \& Assessment Service, 2015).

무지외반증의 발병 원인은 분명하지 않으나 Frey et al.(1993)은 자신의 발보다 작은 신발 착용이 주원인이 라고 보고하였고, Piqué-Vidal et al.(2007)은 유전적 요인이 큰 것으로 보고하였다. 한편, 무지외반증이 발생 하는 신체적 요인으로 높은 체질량지수(body mass index: BMI)가 지목된다. BMI가 높을 경우 발의 아치를 유지하는 인대와 힘줄이 쉽게 느슨해져 후천적으로 내측 종 방향 아치의 높이가 낮아지며, 종골 (calcaneus bone) 이 바깥으로 벌어지는 유연성 편평발(pes planovalgus) 이 발생하여 무지외반증의 발병 원인으로 작용한다 (Nguyen et al., 2010).

무지외반증은 엄지발가락의 외반 각도에 따라 경증 $\left(15^{\circ} \sim 20^{\circ}\right)$, 중등도 $\left(20^{\circ} \sim 40^{\circ}\right)$, 그리고 중증 $\left(40^{\circ}\right.$ 이상)으 로 분류된다(King \& Toolan, 2004). 경증과 중등도 무지 외반증을 방치하면 수술이 필요한 중증으로 악화되기 때문 에 발생 초기에 통증을 감소시키고 엄지발가락의 외반 각 도가 더 증가하지 않도록 유지하는 보존적 치료가 권장된 다(Ferrari et al., 2004). 대표적인 보존적 치료 방법으로 엄지발가락을 내측으로 벌려주는 기능을 가진 플라스틱 재 질의 보조기 착용이 권장되지만(Sammarco \& Nichols, 2005), 딱딱한 재질 때문에 걷기와 달리기 같은 일상적인 신체활동에 착용이 제한되는 불편함이 크다(Hawke et al., 2008). 이와 같은 불편함을 줄이면서 효과적인 보존 적 치료방법을 모색하는 시도로 테이핑을 통해 무지외반 각도를 교정하는 교정 테이핑 (corrective kinesio taping: CKT)이 시도되고 있으며, Gur et al.(2017)은 일회성 처 치만으로 무지외반 각도의 유의한 개선이 나타났다고 보 고하였다. Karabicak et al.(2015)은 무지외반증 환자
를 대상으로 보조기 착용 없이 서있는 자세에서 발가락을 벌리고 체중을 싣는 간단한 운동을 10 일간 처치한 결과 첫 번째 중족지절관절의 외반 각도를 $3.5^{\circ}$ 감소시키고 통 증을 유의하게 감소시켰으며, 보조기 대신 $\mathrm{CKT}$ 를 적용 한 결과 $\mathrm{CKT}$ 가 무지외반 각도를 감소시켰다고 보고하였 다. 이와 같은 선행 연구 결과는 교정운동과 교정테이핑 이 무지외반증 환자의 보조기를 대신할 수 있는 효과적인 대안이 될 수 있다는 가능성을 시사한다.

무지외반증 환자의 변형된 발의 구조는 통증을 증가시 킬 뿐만 아니라 발가락과 발목을 움직이는 근육과 힘줄의 위치가 바뀌는 원인이 되기 때문에 위치감각 조절에 필수 적인 고유수용성 감각(proprioception)을 감소시키며 (Menz et al., 2005), 고유수용성 감각의 감소는 위치감 각의 저하로 이어져 평형성이 감소되어 보행 시 낙상의 위험을 2배까지 증가시킨다(Koski et al., 1996). 또한 무지외반증 환자는 발의 통증 때문에 보행에 제한이 생기 고 패턴이 변형되며, 이에 따른 잘못된 보행 습관은 무지 외반증 증상을 더욱 악화시키는 악순환으로 이어진다 (Benvenuti et al., 1995). Chopra et al.(2015)은 무 지외반증 환자의 보행에서 뚜렷하게 발견되는 아홉 가지 특징을 걸음 수(cadence)의 감소, 보행 속도(gait speed)의 감소, 중간 입각기 (foot-flat) 시간의 지연, 앞 발로 지면 밀기(push-off) 힘의 감소, 최대 유각기 속도 (peak swing speed)의 감소, 발가락 떼기에서 지면과 발 사이의 각도(toe-off pitch angle)의 감소, 첫 번째 중족 지절관절의 시상면 움직임(first metatarsophalangeal joint sagittal plane movement)의 감소, 그리고 발뒤꿈 치가 지면에 닿은 총 시간과 엄지발가락이 지면을 누르는 최대 수직 압력(total contact duration at hind foot and peak vertical force at the first toe)의 감소라고 제 시하였다. 이와 같은 보행분석 매개변수를 통한 평가방법 은 방사선 촬영으로는 관찰이 어려운 발의 기능적·역학적 평가를 가능하게 만들어 중증 무지외반증 환자가 수술 후 교정이 잘 이루어졌는지 여부를 평가하는 기준으로도 효 과적으로 이용된다(Moerenhout et al., 2019).

지금까지 무지외반증 환자를 대상으로 수행된 연구는 운동보다는 수술 또는 보조기 사용이 무지외반 각도의 교 정에 미치는 영향을 규명하는 연구가 주를 이루었다 (Sammarco \& Nichols, 2005; Trnka et al., 2013). 그 
러나 최근 보행에서 발생하는 발과 발목의 문제를 해결하 기 위해서 다양한 교정운동 (corrective exercise: CEX) 이 제안되고 있다(Payandeh et al., 2014). Lee et al. (2015)은 무지외반증 환자를 대상으로 6주간 주로 비 체중부하 자세에서 발과 발목의 움직임에 관여하는 근육 의 운동을 처치하였는데, 정적 균형능력은 개선된 반면 정적 족저압의 유의한 변화가 나타나지 않았다고 보고하 면서, 그 원인이 대상자에 대한 교육의 부족과 운동처치 기간의 부족이라고 주장하였다. 한편, Schuh et al. (2009)은 무지외반증 환자를 대상으로 물리치료와 함 께 보행훈련과 발가락 굽힘근, 저측굴곡근, 그리고 골반 저근 재활운동을 병행하여 처치한 결과 발가락으로의 족 저압 이동이 가능하다고 보고하였다. 또한 Richards et al. (2018)은 족저압 분석 기능이 있는 트레드밀에서 보 행 교정운동을 실시한 결과 대상자의 보폭(step length) 과 저측굴곡 각도가 증가되었으며, 골반에 대한 대퇴골의 내전 각도를 감소시켰다고 보고하였다. 이상의 선행 연구 는 무지외반증 환자의 잘못된 보행 습관을 개선하기 위하 여 정적인 운동보다는 보행 교정운동이 더 필요하다는 것 을 보여준다. 무지외반증이 악화되어 중증으로 이어질 경 우 유일한 치료 방법은 수술이기 때문에(Deenik et al., 2008), 경증 및 중등도 무지외반증 환자에게 운동을 통 한 보존적 치료를 적용하여 효과를 얻음으로서 수술까지 이어지지 않도록 하는 것은 매우 중요하다(Schuh et al., 2009; Karabicak et al., 2015).

이 연구의 목적은 보행 시 통증이 있고, 보존적 치료가 권장되는 20 30대 여성 중등도 무지외반증 환자를 대상 으로 일회성 $\mathrm{CEX}$ 처치, $\mathrm{CKT}$ 처치, 그리고 $\mathrm{CEX}+\mathrm{CKT}$ 처 치가 보행 패턴, 족저압, 평형성, 그리고 통증에 미치는 영향을 규명하는 것이었다. 세 처치의 결과를 비교하여 운동을 통한 보존적 치료에 효과적인 방안을 모색하고 장 기간의 종단적 연구를 위한 발판을 마련하고자 하였다.

\section{연구 방법}

\section{연구 대상자}

이 연구의 대상자는 $\mathrm{S}$ 시와 $\mathrm{G}$ 도에 거주하는 중등도 무
지외반증을 가진 20대 30 대 여성 31명의 자발적 신청 을 받아 모집되었다. 모집된 대상자는 $\mathrm{S}$ 시 $\mathrm{Y}$ 구에 위치한 $\mathrm{P}$ 정형외과에서 무지외반 각도 측정과 전문의의 진단을 받았다. 진단 결과, (1) 엄지발가락과 중족골 뼈 사이의 각 도가 $20^{\circ}$ 이상과 $40^{\circ}$ 이하에 해당하고, (2) 보행 시 엄지발 가락 부위에 통증이 있고, (3) 무지외반증을 제외한 다른 족부 질환 및 무릎과 골반의 질환이 없고, (4) 무지외반증 통증으로 수술을 받은 적이 없으며, (5) 무지외반증 교정 을 위한 운동 지도를 받아 본 경험이 없는 자 21 명을 최종 연구 대상자로 선정하였다.

연구가 시작되기 전 연구 목적과 절차에 대하여 설명 하였으며, 이를 이해하고 참여하고자 하는 대상자로부터 검사 동의서를 받고 연구에 참여하도록 하였다. 연구 대 상자의 신체적 특성은 〈Table 1)에 제시된 바와 같다.

Table 1. Physical characteristics of participants

\begin{tabular}{cc}
\hline \hline Variables & mean \pm SD \\
\hline Age $(\mathrm{yrs})$ & $30.1 \pm 5.1$ \\
Height $(\mathrm{cm})$ & $164.1 \pm 4.8$ \\
Body weight $(\mathrm{kg})$ & $56.7 \pm 6.8$ \\
Body mass index $\left(\mathrm{kg} \cdot \mathrm{m}^{-2}\right)$ & $21.2 \pm 5.7$ \\
Hallux valgus angle $\left({ }^{\circ}\right)$ & $27.2 \pm 6.1$ \\
\hline \hline
\end{tabular}

\section{실험 절차}

21명의 대상자를 7명씩 3개 팀으로 나눈 후 counterbalanced oder에 따라 CEX처치, CKT처치, 그리고 $\mathrm{CEX}+\mathrm{CKT}$ 처치에 각각 1 회씩 총 3 회 반복 참여하도록 하였다. 세 처치 간에 일주일간의 wash-out 기간을 두어 전의 처치가 다음 처치에 미치는 영향을 최소화 하였다 (Luca et al., 2017). 각 처치 전 사전검사를 하고, 해당 처치를 한 후 사전검사와 동일한 방법으로 사후검사를 실 시하여 모든 종속변인을 세 처치 간에, 그리고 두 시기 간 에 동시에 비교하였다. 세 가지 처치 전 측정 결과를 보 면, 세 처치 간에 통계적으로 유의한 차이가 없었다.

\section{측정 항목과 방법}

이 연구의 대상자 측정은 $\mathrm{S}$ 시 $\mathrm{G}$ 구에 위치한 $\mathrm{C}$ 교정운 
동 교육센터 실험실에서 이루어졌다. 각 처치 전과 후에 동일한 방법으로 각 종속변인을 측정하였으며, 모든 대상 자에게 각 처치 전 24 시간 전부터 과격한 운동을 피하고 7시간 이상 숙면을 취한 후 실험실에 방문하도록 지시하 였다. 보행분석 후 내측 주상골 높이 검사, 평형성 검사, 그리고 통증 자각도 검사 순으로 측정을 진행하였다. 처 치 전, 후 검사에 소요된 시간은 약 10 분이었다. 모든 검 사와 측정은 교정운동 지도 경력이 5년 이상인 교정운동 전문가에 의해서 진행되었다.

\section{1) 체격과 무지외반 각도}

신장과 체중은 각각 신체구성 측정기(X-Scan plus $\mathrm{II}$, 한국)와 체중계 $(\mathrm{HE}-70, \mathrm{CAS}$, 한국)를 이용하여 측 정하였고, 체중 $(\mathrm{kg})$ 을 신장의 제곱 $\left(\mathrm{m}^{2}\right)$ 으로 나누어 체질 량지수(body mass index: BMI)를 산출하였다. 무지외 반 각도는 X-ray(BL-50, DK Medical Systems, 한국) 를 이용하여 측정하였다.

\section{2) 보행 패턴, 보행주기 및 족저압}

보행 중 족저압과 보행 패턴은 압력 분포 분석기 (FDM-T, Zebris Medical, 독일)를 이용해서 검사하였다. 이 검사 장비의 급내 상관계수(intra-class correlation coefficient: ICC)는 0.9 로 우수한 신뢰도를 보였다 (Nüeach et al. 2018). 이 검사 장비의 크기는 $212 \times$ $60.5 \times 2.1 \mathrm{~cm}(\mathrm{~L} \times \mathrm{B} \times \mathrm{H})$ 이며, 10,240 개의 감지기가 감지 발판 (sensor plate)에 $0.85 \times 0.85 \mathrm{~cm}$ 간격으로 내 장되어 있으며, 그 위에는 일반 트레드밀(treadmill)과 동일하게 벨트가 움직인다. 대상자가 걸을 때 발생하는 압력 중심 경로를 발이 닿는 위치에 따라 $120 \mathrm{~Hz}$ 의 속도 로 3차원적으로 측정하여 전용 프로그램을 통해 시각화 하도록 하였다. 보행 시 속도는 $0.5 \mathrm{~km} / \mathrm{h}$ 에서 시작하여 매 15 초마다 $0.4 \mathrm{~km} / \mathrm{h}$ 씩 증가시켰으며, 각 대상자가 걷 기에 적당하다고 표시하는 속도에서 1 분간 적응하도록 한 후, 그 속도에서 1 분간 측정을 하였다.

(1) 보폭(step length), (2) 입각기 내에서 형성된 발의 압력중심 (center of pressure: $\mathrm{CoP}$ )의 이동 길이인 입각 기 발의 앞, 뒤 길이 (single support line), (3) 걸음 수 (cadence), (4) 입각기 내에서 발의 앞부분이 바닥에 닿아 있는 시간인 전 족부 접촉 시간(forefoot contact time),
(5) 발의 중간 부분이 바닥에 닿아있는 시간인 중족부 접 촉 시간(midfoot contact time), (6) 발의 뒤꿈치 부분이 바닥에 닿아있는 시간인 뒤꿈치 접촉 시간(heel contact time), (7) 전체 보행 주기에서 양쪽 발이 동시에 바닥에 닿아 있는 시기가 차지하는 양 하지 지지기(double stance phase), (8) 보행의 입각기 구간 중 전족부로 바닥 을 누르는 동안에 형성된 전족부 최대 압력(forefoot maximum pressure), (9) 중족부로 바닥을 누르는 동안 에 형성된 중족부 최대 압력(midfoot maximum pressure), 그리고 (10) 뒤꿈치로 바닥을 누르는 동안에 형 성된 뒤꿈치 최대 압력(heel maximum pressure)이었 다.

\section{3) 평형성}

평형성을 평가하기 위하여 눈감고외발서기를 실시하 였다. 눈을 감고 한쪽 다리를 들어 무릎을 $90^{\circ}$ 각도로 굽 혀 몸의 균형을 유지하는 시간을 0.1 초 단위로 측정하였 다. 좌, 우 2회씩 측정하여 평균값을 기록하였다. 족저압 을 포함한 평형성을 평가하기 위하여 서있는 자세에서 압 력분포 분석기(FDM-T, Zebris Medical, 독일)를 사용 해서 족저압을 측정하였다. 이 검사 장비의 평형성 측정 을 위한 ICC는 0.77 0.9로서 우수한 신뢰도를 보였다 (Pau et al., 2015). 대상자가 감지 발판 위에 서 있을 때, 10,240 개의 센서가 $0.85 \times 0.85 \mathrm{~cm}$ 간격으로 내장 되어 있는 감지 발판을 발이 수직으로 누르는 힘 (reactive-normal force)을 $120 \mathrm{~Hz}$ 의 속도로 기록하였 다. 대상자가 눈을 뜬 상태로 발판 위에서 20 초간 서 있 도록 하면서 측정하였다.

이 검사장비에서 측정한 변인은 (1) 발의 압력중심 경로 가 이동한 시상면과 관상면 값을 타원 형태로 보여주는 95\% 압력중심 경로 타원 값(95\% confidence ellipse area), (2) 시상면과 관상면 상에서 발의 압력중심 경로가 이동한 전체 길이를 보여주는 압력 중심 경로 전체 길이 (CoP path length), 그리고 (3) 오른쪽 다리와 왼쪽 다리 에 실리는 체중의 차이와 후족부 힘 값의 평균 비율을 보 여주는 후족부 평균 힘(back foot average force)이었다.

\section{4) 주상골 높이 검사}

발의 주상골(navicular bone) 높이는 무지외반 각도가 
더 큰 발에서 측정하였다. 먼저 $10 \%$ 체중 주상골 높이를 측정한 후 $90 \%$ 체중 주상골 높이를 측정하여 $0.1 \mathrm{~cm}$ 단 위로 기록하였다. 체중부하의 $10 \%$ 와 $90 \%$ 로 서 있는 상태 에서 직각측정기(Combination Square, Stanley, 미국) 를 사용하여 각각 2 회씩 반복 측정한 후 평균값을 산출하 였다. 이 검사 방법의 ICC는 체중부하의 $10 \%$ 에서 .811, 그리고 체중부하의 $90 \%$ 에서 .851이었다(Williams \& McClay, 2000).

\section{5) 통증 척도}

시각적 통증 척도 검사지(visual analogue scale: $\mathrm{VAS})$ 를 사용해서 세 가지 처치 후 통증 척도를 검사하였 다. 이 검사지의 $\mathrm{ICC}$ 는 .97로서 검사-재검사 신뢰도가 매우 높다. 검사지에 $10 \mathrm{~cm}$ 의 가로로 긴 막대 모양의 수 평선이 있다. 선이 시작되는 가장 왼쪽은 통증이 없는 상 태로, 그리고 선이 끝나는 가장 오른쪽은 매우 심한 통증 이 있는 상태로 표시되어 있다. 대상자로 하여금 측정 당 시에 자신이 느끼는 통증 정도를 그 선상에 표시하도록 한 후 그 길이를 $0.1 \mathrm{~cm}$ 단위로 측정하여 통증 정도를 기 록하였다(Bijur et al., 2001).

\section{처치 방법}

1) 교정운동처치(corrective exercise: CEX)

이 연구에서 적용한 $\mathrm{CEX}$ 처치는 미국스포츠의학아카 데미(National Academy of Sports Medicine)의 교정운 동 연속체 (corrective exercise continuum) 계획에 맞춰 자가근막이완(self myofascial release)에 의한 억제기 법, 자기체중을 이용한 활성화기법, 보행을 통한 통합기 법으로 구성되었다(Clark \& Lucett, 2010; Jafari et al., 2019)

자가근막이완은 지름 $5 \mathrm{~cm}$, 길이 $15 \mathrm{~cm}$ 인 미니 폼롤 러(Miniroll, Blackroll, 독일)를 사용하였으며, 체중의 $50 \%$ 부하를 기준으로 통증을 느끼지 않는 범위까지 강도 를 증가시켜 발바닥은 아치를 중심으로 뒤꿈치와 앞꿈치 사이, 종아리는 뒤꿈치 위에서 무릎 뒤 까지 각 3 분씩 자 가근막이완 하였으며, 총 6 분 소요되었다(Grieve et al.,2015). 자기체중을 이용한 교정운동은 Schuh et al. (2009)에서 제시된 무지외반증 수술 후 재활훈련 프
로그램을 수정하여 지도하였으며, 모든 운동은 서서 발에 체중을 지탱한 상태에서 진행되었다. 장무지굴근과 장지 굴근의 굴곡 운동, 발목관절 저측굴곡근 운동, 골반관절 안정근 운동으로 구성되었으며 종목별로 5 분씩 20회, 3 세트를 반복하였고, 총 20 분 소요되었다. 보행 교정운동 은 대상자가 평상시 걷는 속도를 선택하게 하여 1.8 4.5 $\mathrm{km} / \mathrm{h}$ 범위에서 진행하였다(Chopra et al., 2015). 보행 교정운동은 발의 아치를 유지하며 뒤꿈치 닿기를 5 분간 반복 진행한 후 발가락 굴곡근을 사용하여 바닥을 밀어내 는 동작을 5 분간 반복 진행하였다(Shamus et al.,2004; Schuh et al., 2009). 모든 교정운동 처치는 교정운동 지도 경력이 5 년 이상인 교정운동 전문가에 의하여 진행되었다.

2) 교정테이핑처치(corrective kinesio taping: CKT) 이 연구에서 적용한 CKT처치는 교정운동 지도 경력이 5년 이상인 교정운동 전문가가 선행 연구(Jeon et al., 2004; Karabicak et al., 2015)를 참고하여 다음과 같 이 실시하였다.

탄성 테이프를 가로 $5 \mathrm{~cm}$, 세로 $20 \mathrm{~cm}$ 길이로 2장, 그 리고 가로 $5 \mathrm{~cm}$, 세로 $7.5 \mathrm{~cm}$ 길이로 1장을 잘랐다. 가로 $5 \mathrm{~cm}$, 세로 $20 \mathrm{~cm}$ 길이로 자른 두 장의 테이프를 엄지발가 락 안쪽부터 덮듯이 붙이고 $50 \%$ 장력으로 발 안쪽 내측 복사뼈 방향으로 주행할 수 있도록 붙였다. 가로 $5 \mathrm{~cm}$, 세 로 $12.5 \mathrm{~cm}$ 길이로 자른 테이프를 $80 \%$ 장력으로 무지외 반증이 있는 부위에 세로 방향으로 붙이고 끝 부분은 각 각 발바닥 쪽과 발등 쪽에 고정시켰다. 시작되는 $4 \mathrm{~cm}$ 지 점과 끝나는 $4 \mathrm{~cm}$ 지점은 늘리지 않고 붙였다.

\section{3) 복합처치 $(\mathrm{CEX}+\mathrm{CKT})$}

$\mathrm{CEX}+\mathrm{CKT}$ 처치는 이상에서 기술한 방법에 따라 교정 테이핑처치를 한 후 교정운동 처치를 진행하였다.

\section{자료처리 방법}

이 연구에서 얻은 결과는 $\mathrm{SPSS} \mathrm{PC} \mathrm{PC}^{+}$for Windows (version 23.0) 통계 프로그램을 이용하여 분석하였다. 기술통계량을 제시하기 위하여 평균(mean)과 표준편차 (standard deviation: $S D$ )를 산출하였다. 세 처치 간, 그리고 두 시기 간 종속변인의 차이를 동시에 분석하기 
위하여 반복 이원분산분석 (repeated two-way ANOVA) 을 실시하였다. 처치의 주효과, 시기의 주효과, 또는 처치 와 시기의 상호작용이 유의한 경우, 세 처치 간 평균 차이 의 분석을 위하여 일원분산분석(one-way ANOVA)과 최 소 유의차 검증법 (least significant difference: LSD)을 실시하였고, 두 시기 간 평균 차이의 분석을 위하여 종속 t검증 (paired t-test)을 실시하였다. 모든 통계분석의 유 의수준 $(\alpha)$ 은 .05로 설정하였다.

\section{연구 결과}

보행 패턴과 관련하여, 보폭, 입각기 발의 앞, 뒤 길이, 그리고 걸음 수에서 시기의 주효과 및 처치와 시기의 상 호작용이 유의하게 나타났다. 보폭은 처치 전과 비교하여 $\operatorname{CEX}(p<.001)$ 처치 후 $12.3 \%$ 증가되었고, $\mathrm{CEX}+\mathrm{CKT}$ ( $p$ <.001)처치 후 8.5\% 증가되었다. 입각기 발의 앞, 뒤 길이는 처치 전과 비교하여 $\mathrm{CEX}$ ( $p$ <.01)처치 후 $13.9 \%$ 증가되었고, $\mathrm{CEX}+\mathrm{CKT}(p<.05)$ 처치 후 $5.9 \%$ 증가되었 다. 걸음 수는 처치 전과 비교하여 $\operatorname{CEX}(p<.001)$ 처치 후 $9.8 \%$ 감소되었고, $\mathrm{CEX}+\mathrm{CKT}(p<.001)$ 처치 후 $6.4 \%$ 감소되었다〈Table 2$\rangle$.

보행 주기와 관련하여, 전족부 접촉 시간, 중족부 접촉 시간, 뒤꿈치 접촉 시간, 그리고 양 하지 지지기에서 시기 의 주효과 및 처치와 시기의 상호작용이 유의하게 나타났 다. 전족부 접촉 시간은 처치 전과 비교하여 $\operatorname{CEX}(p<.001)$ 처치 후 $2.5 \%$ 감소되었고, $\mathrm{CEX}+\mathrm{CKT}(p<.001)$ 처치 후 $2.3 \%$ 감소되었다. 중족부 접촉 시간은 처치 전과 비교하 여 $\mathrm{CEX}(p<.001)$ 처치 후 $2.9 \%$ 감소되었고, $\mathrm{CEX}+\mathrm{CKT}$ ( $p$ <.01)처치 후 $3.0 \%$ 감소되었다. 뒤꿈치 접촉 시간은 처치 전과 비교하여 $\mathrm{CEX}(p<.001)$ 처치 후 $7.7 \%$ 감소되 었고, $\mathrm{CEX}+\mathrm{CKT}(p<.001)$ 처치 후 $6.6 \%$ 감소되었다. 양 하지 지지기는 처치 전과 비교하여 $\mathrm{CEX}(p<.01)$ 처치 후 $10.7 \%$ 감소되었지만, $\operatorname{CKT}(p<.01)$ 처치 후에는 $2.3 \%$ 증가되었다〈Table 3 .

보행시 전, 중족부 및 뒤꿈치 족저압과 관련하여, 전족 부 최대 압력에서 처치와 시기의 상호작용이 유의하게 나 타났다. 중족부 최대 압력과 뒤꿈치 최대 압력에서는 시 기의 주효과가 유의하게 나타났다. 전족부 최대 압력은
처치 전과 비교하여 $\mathrm{CKT}(p<.001)$ 처치 후 $6.1 \%$ 감소되 었지만, $\mathrm{CEX}(p<.05)$ 처치 후에는 $7.4 \%$ 증가되었다. 중 족부 최대 압력은 처치 전과 비교하여 $\mathrm{CEX}+$ $\operatorname{CKT}(p<.05)$ 처치 후 $10.1 \%$ 증가되었다. 뒤꿈치 최대 압 력은 처치 전과 비교하여 $\operatorname{CEX}(p<.05)$ 처치 후 $8.3 \%$ 증 가되었고, $\mathrm{CEX}+\mathrm{CKT}(p<.05)$ 처치 후 $12.0 \%$ 증가 되었 다〈Table 4$\rangle$.

평형성과 관련하여, 눈감고외발서기에서 시기의 주효 과가 유의하게 나타났다. 후족부 평균 힘에서 시기의 주 효과 및 처치와 시기의 상호작용이 유의하게 나타났다. 눈감고외발서기는 처치 전과 비교하여 $\mathrm{CKT}(p<.001)$ 처 치 후 $45.8 \%$ 증가되었고, $\operatorname{CEX}(p<.01)$ 처치 후 $30.8 \%$ 증가되었다. 후족부 평균 힘은 처치 전과 비교하여 $\mathrm{CEX}(p<.01)$ 처치 후 8.9\% 증가되었다〈Table 5〉.

주상골 높이와 관련하여, $10 \%$ 체중 주상골 높이와 90\% 체중 주상골 높이에서 처치의 주효과, 시기의 주효 과 및 처치와 시기의 상호작용이 유의하게 나타나지 않았 다〈Table 6〉.

통증과 관련하여, 시각적 통증 척도에서 시기의 주효 과가 유의하게 나타났으며, 처치 전과 비교하여 $\mathrm{CKT}(p<.05)$ 처치 후 $38.5 \%$ 감소되었고, $\mathrm{CEX}+$ $\mathrm{CKT}(p<.01)$ 처치 후 $34.8 \%$ 감소되었다〈Table 7 .

\section{논 의}

\section{보행 패턴의 변화}

이 연구에 참여한 20 30대 여성 중등도 무지외반증 환자의 평상시 보행 속도는 $0.5 \sim 1.5 \mathrm{~m} / \mathrm{s}$ 였으며, 평균 보행 속도는 $0.90 \mathrm{~m} / \mathrm{s}$ 로 Ahn \& Jung(2001)이 제시한 20 30대 한국 여성의 평균 보행 속도인 $1.27 \mathrm{~m} / \mathrm{s}$ 보다 크게 낮은 것으로 나타났다. 무지외반증 환자의 보행 속 도가 느린 이유는 보행 시 보폭이 짧기 때문이며, 이는 입 각기의 마지막 단계인 발끝으로 바닥을 밀어내는 동작 중 첫 번째 중족지절관절의 통증으로 인하여 엄지발가락 까 지 힘을 싣지 못 하기 때문이다(Wen et al., 2012). 또한 이 연구에 참여한 대상자의 세 가지 처치 전 평균 보폭은 $55.2 \mathrm{~cm}$ 로 Park \& Kim(2002)이 제시한 표준 체중을 
Table 2. Gait patterns obtained during three trials

$($ mean $\pm S D)$

\begin{tabular}{|c|c|c|c|c|c|c|c|c|}
\hline \multirow{2}{*}{ Variables } & \multirow{2}{*}{ Trials } & \multicolumn{2}{|c|}{ Time } & \multirow{2}{*}{\multicolumn{2}{|c|}{$\Delta \%$}} & & \multirow[b]{2}{*}{$p$} & \\
\hline & & Pre & Post & & & & & \\
\hline \multirow{3}{*}{$\begin{array}{l}\text { Step length } \\
\quad(\mathrm{cm})\end{array}$} & CEX & $54.7 \pm 7.7$ & $61.4 \pm 6.5$ & $* * *$ & 12.25 & Trial & .312 & \\
\hline & CKT & $55.3 \pm 7.3$ & $55.0 \pm 6.9$ & & -0.54 & Time & .000 & $+1+$ \\
\hline & $\mathrm{CEX}+\mathrm{CKT}$ & $55.5 \pm 7.6$ & $60.2 \pm 6.2$ & $* * *$ & 8.47 & Trial*Time & .000 & $\mathrm{HH}$ \\
\hline \multirow{3}{*}{$\begin{array}{l}\text { Single support line } \\
(\mathrm{mm})\end{array}$} & CEX & $105.7 \pm 12.1$ & $120.4 \pm 13.5$ & $* *$ & 13.91 & Trial & .388 & \\
\hline & CKT & $107.2 \pm 14.3$ & $107.7 \pm 12.5$ & & 0.47 & Time & .000 & $+1+$ \\
\hline & $\mathrm{CEX}+\mathrm{CKT}$ & $109.1 \pm 14.2$ & $115.5 \pm 17.6$ & $*$ & 5.87 & Trial*Time & .015 & H \\
\hline \multirow{3}{*}{$\begin{array}{l}\text { Cadence } \\
\left(\text { step } \cdot \min ^{-1}\right)\end{array}$} & CEX & $104.8 \pm 10.9$ & $94.5 \pm 12.7$ & $* * *$ & -9.83 & Trial & .523 & \\
\hline & CKT & $103.1 \pm 11.7$ & $103.6 \pm 12.1$ & & 0.48 & Time & .000 & +H \\
\hline & $\mathrm{CEX}+\mathrm{CKT}$ & $103.0 \pm 11.3$ & $96.4 \pm 15.2$ & $* * *$ & -6.41 & Trial*Time & .000 & H+ \\
\hline
\end{tabular}

CEX: corrective exercise, CKT: corrective kinesio taping; $++p<.01,+1+p<.001$ : Significant main effect and/or interaction;

${ }^{*} p<.05,{ }^{* *} p<.01,{ }^{* * *} p<.001$ : Significant difference between pre- and post-test.

Table 3. Gait cycle obtained during three trials

$($ mean $\pm S D)$

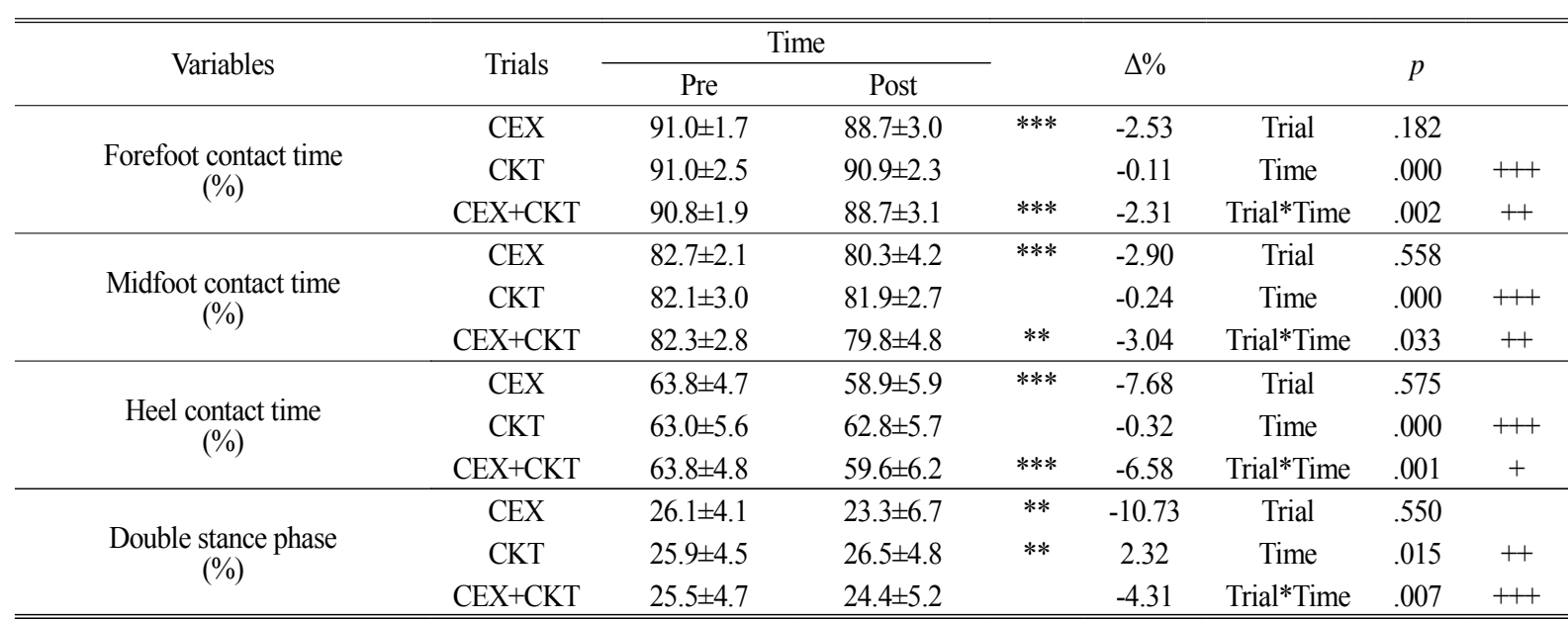

CEX: corrective exercise, CKT: corrective kinesio taping; $+p<.05,++p<.01,+++p<.001$ : Significant main effect and/or interaction;

${ }^{* *} p<.01,{ }^{* * *} p<.001$ : Significant difference between pre- and post-test.

Table 4. Foot pressures obtained during three trials

$($ mean $\pm S D)$

\begin{tabular}{|c|c|c|c|c|c|c|c|c|}
\hline \multirow{2}{*}{ Variables } & \multirow{2}{*}{ Trials } & \multicolumn{2}{|c|}{ Time } & \multirow{2}{*}{\multicolumn{2}{|c|}{$\Delta \%$}} & & \multirow{2}{*}{$p$} & \\
\hline & & Pre & Post & & & & & \\
\hline \multirow{3}{*}{$\begin{array}{l}\text { Forefoot maximum pressure } \\
\qquad\left(\mathrm{N} \cdot \mathrm{cm}^{2}\right)\end{array}$} & CEX & $31.2 \pm 6.3$ & $33.5 \pm 5.8$ & $*$ & 7.37 & Trial & .395 & \\
\hline & CKT & $31.0 \pm 5.9$ & $29.1 \pm 5.2$ & $* * *$ & -6.13 & Time & .846 & \\
\hline & $\mathrm{CEX}+\mathrm{CKT}$ & $31.5 \pm 6.2$ & $31.5 \pm 6.2$ & & 0.00 & Trial*Time & .006 & +++ \\
\hline \multirow{3}{*}{$\begin{array}{l}\text { Midfoot maximum pressure } \\
\qquad\left(\mathrm{N} \cdot \mathrm{cm}^{2}\right)\end{array}$} & CEX & $15.1 \pm 3.3$ & $15.9 \pm 3.3$ & & 5.30 & Trial & .932 & \\
\hline & CKT & $15.2 \pm 3.8$ & $15.2 \pm 3.5$ & & 0.00 & Time & .017 & + \\
\hline & $\mathrm{CEX}+\mathrm{CKT}$ & $14.8 \pm 2.7$ & $16.3 \pm 3.7$ & $*$ & 10.14 & Trial*Time & .119 & \\
\hline \multirow{3}{*}{$\begin{array}{l}\text { Heel maximum pressure } \\
\left(\mathrm{N} \cdot \mathrm{cm}^{2}\right)\end{array}$} & CEX & $25.2 \pm 4.6$ & $27.3 \pm 5.0$ & $*$ & 8.33 & Trial & .291 & \\
\hline & CKT & $24.3 \pm 3.8$ & $24.4 \pm 3.6$ & & 0.41 & Time & .001 & $+1+$ \\
\hline & $\mathrm{CEX}+\mathrm{CKT}$ & $24.2 \pm 3.4$ & $27.1 \pm 6.1$ & $*$ & 11.98 & Trial*Time & .081 & \\
\hline
\end{tabular}

CEX: corrective exercise, CKT: corrective kinesio taping; $++p<.01,++p<.001$ : Significant main effect and/or interaction;

$*_{p}<.05,{ }^{* * *} p<.001$ : Significant difference between pre- and post-test. 
160 Tae-Geun Yoo et al.

Table 5. Balance obtained during three trials

$($ mean $\pm S D)$

\begin{tabular}{|c|c|c|c|c|c|c|c|c|}
\hline \multirow{2}{*}{ Variables } & \multirow{2}{*}{ Trials } & \multicolumn{2}{|c|}{ Time } & \multirow{2}{*}{\multicolumn{2}{|c|}{$\Delta \%$}} & \multirow{2}{*}{\multicolumn{2}{|c|}{$p$}} & \multirow{2}{*}{$p$} \\
\hline & & Pre & Post & & & & & \\
\hline \multirow{3}{*}{$\begin{array}{l}\text { One leg standing with eyes closed } \\
\qquad(\mathrm{sec})\end{array}$} & CEX & $26.3 \pm 23.4$ & $34.4 \pm 28.6$ & $* *$ & 30.80 & Trial & .992 & \\
\hline & CKT & $24.0 \pm 20.0$ & $35.0 \pm 23.2$ & $*$ & 45.83 & Time & .004 & H+ \\
\hline & $\mathrm{CEX}+\mathrm{CKT}$ & $29.3 \pm 20.8$ & $30.6 \pm 21.9$ & & 4.44 & Trial*Time & .195 & \\
\hline \multirow{3}{*}{$95 \%$ confidence ellipse area $\left(\mathrm{mm}^{2}\right)$} & CEX & $191.8 \pm 254.8$ & $140.0 \pm 94.6$ & & -27.01 & Trial & .849 & \\
\hline & CKT & $195.0 \pm 225.5$ & $128.2 \pm 106.1$ & & -34.26 & Time & .502 & \\
\hline & $\mathrm{CEX}+\mathrm{CKT}$ & $156.3 \pm 174.7$ & $215.8 \pm 211.9$ & & 38.07 & Trial*Time & .164 & \\
\hline \multirow{3}{*}{ Center of pressure path length $(\mathrm{mm})$} & CEX & $185.2 \pm 103.6$ & $184.3 \pm 109.5$ & & -0.49 & Trial & .839 & \\
\hline & CKT & $206.2 \pm 132.5$ & $163.2 \pm 83.1$ & & -20.85 & Time & .458 & \\
\hline & $\mathrm{CEX}+\mathrm{CKT}$ & $171.2 \pm 119.7$ & $173.7 \pm 82.2$ & & 1.46 & Trial*Time & .538 & \\
\hline \multirow{3}{*}{ Back foot average force $(\%)$} & CEX & $60.5 \pm 10.7$ & $65.9 \pm 9.1$ & $* *$ & 8.93 & Trial & .919 & \\
\hline & CKT & $65.1 \pm 11.5$ & $63.2 \pm 10.4$ & & -2.92 & Time & .032 & + \\
\hline & $\mathrm{CEX}+\mathrm{CKT}$ & $61.2 \pm 12.0$ & $64.8 \pm 10.6$ & & 5.88 & Trial*Time & .022 & + \\
\hline
\end{tabular}

CEX: corrective exercise, CKT: corrective kinesio taping; $+p<.05,+++p<.001$ : Significant main effect and/or interaction;

${ }^{*} p<.05,{ }^{* *} p<.01$ : Significant difference between pre- and post-test.

Table 6. Navicular bone height obtained during three trial

$($ mean $\pm S D)$

\begin{tabular}{|c|c|c|c|c|c|c|}
\hline \multirow{2}{*}{ Variables } & \multirow{2}{*}{ Trials } & \multicolumn{2}{|c|}{ Time } & \multirow{2}{*}{$\Delta \%$} & & \multirow{2}{*}{$p$} \\
\hline & & Pre & Post & & & \\
\hline \multirow{3}{*}{$\begin{array}{l}\text { Navicular bone height at } \\
10 \% \text { of body weight }(\mathrm{cm})\end{array}$} & CEX & $6.1 \pm 0.4$ & $6.1 \pm 0.4$ & 0.00 & Trial & .775 \\
\hline & CKT & $6.2 \pm 0.4$ & $6.1 \pm 0.4$ & -1.61 & Time & .635 \\
\hline & $\mathrm{CEX}+\mathrm{CKT}$ & $6.1 \pm 0.4$ & $6.2 \pm 0.4$ & 1.64 & Trial*Time & .372 \\
\hline \multirow{3}{*}{$\begin{array}{l}\text { Navicular bone height at } \\
90 \% \text { of body weight }(\mathrm{cm})\end{array}$} & CEX & $5.6 \pm 0.5$ & $5.6 \pm 0.5$ & 0.00 & Trial & .878 \\
\hline & CKT & $5.7 \pm 0.5$ & $5.6 \pm 0.5$ & -1.75 & Time & .643 \\
\hline & $\mathrm{CEX}+\mathrm{CKT}$ & $5.7 \pm 0.5$ & $5.7 \pm 0.5$ & 0.00 & Trial*Time & .464 \\
\hline
\end{tabular}

CEX: corrective exercise, CKT: corrective kinesio taping.

Table 7. Pain index obtained during three trials

$($ mean $\pm S D)$

\begin{tabular}{|c|c|c|c|c|c|c|c|c|}
\hline \multirow{2}{*}{ Variables } & \multirow{2}{*}{ Trials } & \multicolumn{2}{|c|}{ Time } & & \multirow{2}{*}{$\Delta \%$} & & \multirow{2}{*}{$p$} & \\
\hline & & Pre & Post & & & & & \\
\hline \multirow{3}{*}{ Visual analogue scale $(\mathrm{cm})$} & CEX & $2.5 \pm 1.9$ & $2.0 \pm 1.9$ & & -20.00 & Trial & .275 & \\
\hline & CKT & $1.3 \pm 1.7$ & $0.8 \pm 1.4$ & $*$ & -38.46 & Time & .000 & $+1+$ \\
\hline & $\mathrm{CEX}+\mathrm{CKT}$ & $2.3 \pm 1.8$ & $1.5 \pm 1.6$ & $* *$ & -34.78 & Trial*Time & .563 & \\
\hline
\end{tabular}

CEX: corrective exercise, CKT: corrective kinesio taping; $++p<.001$ : Significant main effect and/or interaction;

${ }^{*} p<.05,{ }^{* *} p<.01$ : Significant difference between pre- and post-test. 
평균 보폭인 $61.6 \mathrm{~cm}$ 에 미치지 못했고, 세 가지 처치 전 평균 걸음 수 역시 한국 여성의 평균 걸음 수인 117 걸음 에 미치지 못하는 104 걸음이었다. 이와 같은 결과를 통 하여 이 연구에 참여한 중등도 무지외반증을 가진 대상자 가 보행 시 발의 통증을 느껴 잘못된 보행 습관이 형성된 것으로 해석된다.

세 가지 처치 전, 후를 비교할 때 $\mathrm{CEX}$ 처치와 $\mathrm{CEX}+$ CKT처치 후 보폭이 유의하게 증가되었다. 특히, $\mathrm{CEX}$ 처 치 후 보폭이 $61.4 \mathrm{~cm}$ 로 증가되어 평균 보폭에 근접하는 결과를 보였다. 이와 관련하여, Franz et al. (2014)은 이 연구의 교정운동 처치와 유사한 형태의 보행 처치를 통하 여 보행 시 말기 입각기에 해당하는 발가락 떼기 (push off) 단계의 힘을 크게 증가시켰다고 보고하여 이 연구의 결과와 유사했다. CEX처치와 CEX+CKT처치 후 보폭 이 유의하게 증가된 것은 $\mathrm{CEX}$ 처치에 포함된 보행 교정 운동에 기인하여 나타난 것이라고 해석되며, $\mathrm{CEX}$ 처치와 비교할 때 $\mathrm{CEX}+\mathrm{CKT}$ 처치 후 보폭의 증가가 적었던 원 인은 CKT처치에 의해 변화된 무지외반 각도가 보행 시 동적 균형감각에 부정적 영향을 주었기 때문으로 해석된 다(Gur et al., 2017).

족저근막염 환자의 경우 무지외반증 환자와 유사하게 보행 시 발의 통증이 심하게 나타나며, 보폭이 짧아지는 특성을 보인다(Yoo et al., 2017). 이 연구에 참여한 대 상자의 세 가지 처치 전 평균 입각기 발의 앞, 뒤 길이는 $107.3 \mathrm{~mm}$ 로서 선행 연구에서 보고된 정상인의 수치 (141.9 mm)는 물론 족저근막염 환자의 수치 (113.2 $\mathrm{mm}$ )보다도 짧은 것으로 나타났다(Yoo et al., 2017). 무지외반증 환자의 발의 앞, 뒤 길이가 짧은 이유는 입각 기의 마지막 단계에서 발가락으로 바닥을 밀어내는 힘이 감소되거나 없기 때문이다(Chopra et al., 2015). 이 연 구에서는 $\mathrm{CEX}$ 처치와 $\mathrm{CEX}+\mathrm{CKT}$ 처치 후 발의 앞, 뒤 길 이가 유의하게 증가되었다. 특히, $\mathrm{CEX}$ 처치 후 세 가지 처치 전 평균인 $105.7 \mathrm{~mm}$ 에서 $120.4 \mathrm{~mm}$ 로 크게 증가 되었으며, 이와 같은 결과는 보행 단계에서 체중 수용기 를 시작으로 발뒤꿈치부터 엄지발가락까지 발의 전체에 걸쳐 체질량 중심의 이동이 증가되었기 때문이라고 해석 된다. 이와 같은 개선이 가능했던 것은 $\mathrm{CEX}$ 처치 중 엄지 발가락 굴곡근을 수축한 후 바닥을 밀어내도록 하는 교정 운동을 실시했기 때문이라고 판단된다(Shamus et al.,2004; Schuh et al., 2009).

무지외반증 환자의 보행 습관은 보폭이 짧고 걸음 수 가 증가되는 경향을 보인다(Chopra et al., 2015). CEX 처치 후 걸음 수가 세 가지 처치 전 평균인 104.8 걸음에 서 94.5 걸음으로, $\mathrm{CEX}+\mathrm{CKT}$ 처치 후 세 가지 처치 전 평균인 103 걸음에서 96.4 걸음으로 유의하게 감소되었 다. 이는 보행 교정운동을 통하여 엄지발가락의 근력이 향상됨으로써 나타난 이상에서 기술한 변인의 변화와 밀 접한 관계가 있다.

한편, 이 연구에서 CKT처치를 통하여 보행 패턴의 유 의한 변화가 나타나지 않았다. 이와 관련하여, MartínezGramage et al. (2016)은 종아리와 발목에 적용한 CKT 처치가 보행에 영향을 미치는 표면 근전도의 변화를 유도 했지만 가동범위에는 유의한 영향을 미치지 못했다고 보 고한 바 있으며, Gur et al.(2017)의 연구에서 CKT를 통한 무지외반 각도 개선 후 오히려 동적 균형 감각이 감 소했다는 결과로 이 연구의 CKT처치 후 보행 패턴 결과 를 해석할 때, 무지외반증 환자에게 CKT처치는 보행 패 턴에 유의한 이득을 제공하지 못 하는 것으로 해석된다.

보행 패턴과 관련된 세 가지 처치의 결과를 볼 때, 무지 외반증 환자의 보행 패턴을 효과적으로 교정하기 위해서 는 CKT처치 없이 CEX처치를 통해서 엄지발가락의 근력 을 향상시키고 고유수용성 감각의 활성화를 유도하는 운 동 중재가 필요하다고 정리할 수 있다.

\section{보행 주기의 변화}

Wen et al.(2012)은 무지외반증 환자와 정상인 간에 보행 시 발의 균형과 타이밍을 비교한 연구에서 무지외반 증 환자가 정상인에 비하여 입각기의 거의 모든 주기에서 발과 지면의 접촉시간이 더 길다고 보고하였다. 특히, 뒤 꿈치 닿기와 중간 입각기, 그리고 발의 내측으로 지면을 딛는 시간이 길어진다고 보고하였으며, 이와 같은 보행 시 중족부의 접촉 시간 증가는 무지외반증 환자에게서 발 견되는 전형적인 특징이다. 따라서 무지외반증 환자의 경 우 수술 후 재활 과정에서 중족부 접촉시간을 줄이는 것 이 운동 중재의 중요한 목표가 된다(Moerenhout et al., 2019).

이 연구에서 $\mathrm{CEX}$ 처치와 $\mathrm{CEX}+\mathrm{CKT}$ 처치 후 세 가지 
처치 전 평균과 비교하여 중족부 접촉 시간을 비롯하여 전족부와 후족부의 접촉시간이 유의하게 감소되는 긍정 적인 결과가 나타났다. 이와 같은 결과는 $\mathrm{CEX}$ 처치와 $\mathrm{CEX}+\mathrm{CKT}$ 처치에 포함된 보행 교정운동 중 실시한 발 이 지면에 닿는 위치 및 고관절과 무를 관절의 움직임에 대한 지도에 의해 나타난 결과라고 판단된다(Shamus et al.,2004; Schuh et al., 2009). 무지외반증 환자의 한 쪽 발에 체중이 실리면 양쪽 발로 서있을 때에 비하여 체 중부하가 증가되기 때문에 통증도 함께 증가된다. 이 때, 통증을 회피하기 위하여 양쪽 발에 체중을 싣는 양 하지 지지기가 증가된다(Chopra et al., 2015).

이 연구의 세 가지 처치 전 평균과 비교하여 $\mathrm{CEX}$ 처치 후 양 하지 지지기가 유의하게 감소되어 긍정적인 변화를 보인 반면, $\mathrm{CEX}+\mathrm{CKT}$ 처치에서는 전, 중, 후족부 접촉 시간의 유의한 변화가 없었고, CKT처치에서는 유의한 증가가 나타났다. 이는 전술한 바와 같이 CKT처치가 근 전도의 변화를 유도할 수는 있으나 보행 주기를 바꾸기에 는 부족하다고 보고한 Pérez-Soriano et al.(2014)의 연 구 결과로 해석할 수 있다. 이상의 결과를 통하여 중등도 무지외반증 환자의 보행 주기의 경우 CKT 단독 처치로 는 유의한 변화를 얻기 어려우며, CEX처치가 동반될 때 긍정적인 변화를 유도할 수 있을 것으로 정리할 수 있다.

\section{보행 시 족저압의 변화}

무지외반증 환자는 보행 시 정상적인 보행 패턴을 가 진 대조군과 비교하여 전족부에서 현저하게 족저압이 감 소되고, 대신 중족부 측면의 족저압이 크게 증가된다 (Chopra et al., 2015). Wen et al.(2012)은 무지외반 증 환자의 보행 시 중족부 측면의 족저압이 증가되는 이 유를 첫 번째 중족골두 부위의 통증에 의한 불편함을 피 하기 위한 적응형 전략으로 해석하였다.

이 연구에서 보행 시 전족부 최대 압력이 세 가지 처치 전 평균인 $31.2 \mathrm{~N} \cdot \mathrm{cm}^{2}$ 에서 $\mathrm{CEX}$ 처치 후 $33.5 \mathrm{~N} \cdot \mathrm{cm}^{2}$ 로 유의하게 증가되었고, 보행 시 뒤꿈치 최대 압력도 25.2 $\mathrm{N} \cdot \mathrm{cm}^{2}$ 에서 $27.3 \mathrm{~N} \cdot \mathrm{cm}^{2}$ 으로 유의하게 증가되었다. 보행 시 전족부의 족저압 감소와 함께 나타나는 뒤꿈치의 족저 압 감소는 무지외반증 환자의 보행 패턴 특징 중 하나로 서, 20 65세 사이의 무지외반증 환자는 보행 중 발뒤꿈
치에 체중을 덜 싣고 발의 중간과 바깥쪽에 체중을 싣는 것이 발견됐는데, 이는 보폭과 보행 속도의 감소 때문인 것으로 보고되었다(Chopra et al., 2015). 이와 같은 선 행 연구에서는 무지외반증 환자의 잘못된 보행 습관을 개 선하기 위하여 보행 시 중족부의 압력을 분산시켜 발뒤꿈 치로 바닥을 딛는 힘과 전족부로 바닥을 밀어내는 힘을 증가시키는 것이 중요하다고 강조하였다. $\mathrm{CEX}$ 처치에서 나타난 보행 시 중족부 접촉 시간의 유의한 감소와 함께 나타난 전족부와 뒤꿈치 최대 압력의 유의한 증가는 $\mathrm{CEX}$ 처치에 포함된 교정운동 중 체중을 싣고 하는 발가 락과 발목의 굴곡 운동, 그리고 골반의 위치를 조절하는 운동이 하지의 고유수용성 감각을 자극시켜 자세제어 능 력을 향상시킨 결과로 판단된다(Edwards, 2007).

한편, CKT처치에서는 전족부 최대 압력이 처치 전과 비교할 때 오히려 유의하게 감소되는 등 $\mathrm{CEX}$ 처치와 상 반되는 결과가 나타났으며, CEX+CKT처치 또한 유의한 변화가 나타나지 않았다. Pérez-Soriano et al.(2014)은 무지외반증 환자를 대상으로 발목 관절에 적용한 $\mathrm{CKT}$ 가 보행 시 발목 관절의 배측굴곡과 저측굴곡의 가동범위, 그리고 족저압의 유의한 변화를 유도하지 못했다고 보고 하였으며, Gur et al.(2017)의 무지외반증 환자를 대상 으로 처치한 CKT처치가 무지외반 각도를 개선하는 효과 는 있었지만 보행 중 동적 균형감각을 오히려 감소시켰다 고 보고한 바 있다. 이와 같은 선행 연구의 결과를 고려할 때, 보행 시 전족부 족저압에서 CKT처치 및 $\mathrm{CEX}+\mathrm{CKT}$ 처치 후 유의한 변화가 없었던 이유는 CKT처치가 CEX 처치의 효과를 상쇄했기 때문으로 해석된다. 족저압의 변 화에서 세 가지 처치의 결과를 볼 때, 보행 시 족저압의 긍정적 변화를 위해서는 CKT처치보다는 CEX처치를 중 심으로 중재가 이루어져야 한다고 정리할 수 있다.

\section{평형성의 변화}

무지외반증은 다양한 신체기능에 영향을 미치며, 특히 평형성을 저하시키는 것으로 알려졌다. Kim et al. (2014)은 무지외반증 환자의 경우 정상인에 비하여 평형 성과 최대산소섭취량이 각각 $9.7 \%$ 와 $8.3 \%$ 낮았고, 슬관 절 신전근의 근력도 정상인에 비하여 유의하게 낮았다고 보고하였다. 이 연구에서 중등도 무지외반증을 가진 대상 
자의 세 가지 처치 전 눈감고외발서기 평균기록은 26.5 초로 한국 20대 여성 기준인 32.6초와 30대 여성 기준인 27.7초에 미치지 못했다(Park et al., 2018). 그러나 $\mathrm{CEX}$ 처치 후 눈감고외발서기 기록이 26.3초에서 34.4초 로 $30.4 \%$ 증가되어 평형성의 유의하게 향상되는 결과를 보였다. 이와 관련하여, Lee et al. (2015)은 중등도 무지 외반증이 있는 20 대 여성 대상자에게 6 주간 발목관절의 내번과 배측굴곡근, 저측굴곡근, 그리고 발가락 굴곡근 운동을 처치한 결과 정적 족저압에는 유의한 변화가 없었 지만 정적 평형성이 유의하게 향상되었다고 보고하여 이 연구의 결과와 일치하였다.

한편, 이 연구의 $\mathrm{CEX}$ 처치에서는 전족부 족저압뿐만 아니라 후족부 족저압도 유의하게 증가되었다. 무지외반 증 환자는 서있는 자세에서 발의 앞쪽과 안쪽 부위에 족 저압이 증가되며, 균형 감각이 저하되고 통증이 증가되기 때문에 후족부의 족저압 증가는 긍정적인 변화로 해석된 다(Shih et al., 2014). 발목 관절에 염좌가 생기면 발목 관절 주변뿐만 아니라 무릎과 골반의 움직임을 만드는 근 육의 수축이 정상 시보다 지연되거나 동원 순서가 뒤바뀐 다(Konradsen et al., 1997). 특히, 만성적인 발목 염좌 가 있는 경우 중둔근(gluteus medius)과 대둔근 (gluteus maximus)의 근활성도가 저하되고 수축이 지 연되며, 이와 같은 변화가 발목 염좌를 재발시킬 수 있기 때문에 발목 관절 재활시 중둔근과 대둔근의 운동을 적극 권고하고 있다(Webster \& Gribble, 2013). 이 연구에서 는 $\mathrm{CEX}$ 처치 시 서서 발과 발목 관절에 체중을 싣고 하는 운동과 함께 중둔근과 대둔근의 운동을 처치하여 Lee et al.(2015)의 연구에서 처치한 운동과 차별화 시켰기 때 문에 평형성과 족저압의 유의한 변화를 유도했던 것으로 해석된다.

Heit et al.(1996)은 발목을 보강하는 형태의 CKT처 치가 고유수용성 감각을 활성화시켜 관절의 위치 감각을 향상시켰다고 보고한 바 있다. 그러나 그 이후에 수행된 CKT처치와 관련된 연구에서는 CKT처치가 고유수용성 감각을 긍정적으로 변화시킬 수는 있지만 평형성과 동적 균형감각에는 유의한 영향을 미치지 못했다고 보고되었 다(Barkoukis et al., 2002). 이 연구에서는 눈감고외발 서기 기록이 세 가지 처치 전 평균인 24초에서 CKT처치 후 35 초로 $48.5 \%$ 이상 큰 폭으로 증가되었다. 또한, 통
계적으로 유의한 변화는 아니었지만 동적 평형성을 평가 하는 $95 \%$ 압력중심 경로 타원 값과 압력중심 경로 길이 가 CKT처치 후 개선되는 경향을 보였다. 이와 같은 결과 는 만성적인 발목 불안정에 의한 통증이 있을 때 테이핑 을 적용할 경우 족저압 분포의 불균형 차이가 감소되고 균형감각이 향상되었다고 보고한 Choi \& Seo(2016)의 연구 결과와 관련이 있으며, CKT처치가 무지외반증으로 인한 통증을 감소시켰고, 그 결과 평형성의 유의한 향상 을 유도한 것으로 해석된다.

이 연구의 결과를 보면, $\mathrm{CEX}$ 처치와 CKT처치에서 평 형성의 유의한 향상이 나타난 반면, $\mathrm{CEX}+\mathrm{CKT}$ 처치에서 는 유의한 변화가 나타나지 않았다. 이와 관련하여, Gur et al.(2017)은 무지외반증 환자에게 CKT처치를 적용한 후 동적 평형성이 저하되었다고 보고하면서 그 원인으로 테이핑 후 근신경 조절 감각이 변화되어 하지를 안정시키 는 능력이 감소된 점을 제시하였다. 선행 연구의 결과를 고려할 때 이 연구의 $\mathrm{CKT}+\mathrm{CEX}$ 처치에서 평형성의 유의 한 변화가 없었던 이유는 CKT처치에 의하여 엄지발가락 의 각도가 $6.8^{\circ}$ 내측 이동된 상태에서 닫힌 사슬 형태의 $\mathrm{CEX}$ 처치가 하지 안정성을 떨어뜨려 움직임 조절에 혼란 을 일으켰기 때문으로 해석된다. 평형성의 변화에서 세 가지 처치의 결과를 볼 때, 무지외반증 환자의 평형성을 효과적으로 개선시키기 위해서는 $\mathrm{CKT}$ 처치 없이 $\mathrm{CEX}$ 처 치를 통해서 골반과 무릎, 발목 관절의 조절을 통해 평형 성을 향상시키는 운동 중재가 필요하다고 정리할 수 있다.

\section{주상골 높이의 변화}

후천성 편평발 변형은 중등도 이상의 무지외반증 환자 에게 주로 발견된다. 중등도 무지외반증에 기인하여 발의 형태가 변형되는 과정에서 첫 번째와 두 번째 발가락으로 체중을 지탱하는 힘이 감소되고, 첫 번째 중족지절관절로 체중을 지탱하는 자세가 족저근막을 늘어나게 만들어 후 천성 편평발 변형이 발생한다(Filardi, 2019). 소실된 아 치를 회복하기 위해서는 발의 내재근과 외재근의 근력을 강화시키기 위하여 발가락을 반복적으로 굴곡하고 발목 관절을 내번하는 타월 컬 운동(towel-curl exercise) 운동 이 권장되며, 운동에 더하여 편평발로 인해 족부의 통증 이 있는 경우 $\mathrm{CKT}$ 처치를 적용하여 아치의 교정과 함께 
통증을 감소시키는 중재적 치료가 필요하다(Lynn et al., 2012).

이 연구에 참여한 대상자의 세 가지 처치 전 주상골 평 균 높이는 10\% 체중에서 $6.1 \sim 6.2 \mathrm{~cm}$, 그리고 $90 \%$ 체 중에서 5.6 5.7 cm로 정상 범위에 속해 있었다 (Williams \& McClay, 2000). 이 연구에서 세 처치에 따 라 유의한 변화가 나타나지 않은 것은 처치 전 주상골 높 이가 정상 범위에 있었다는 점, 그리고 일회성 처치에 의 하여 주상골 높이가 쉽게 변하지 않을 가능성이 크다는 점으로 해석할 수 있다. 향후 주상골의 높이가 정상 범위 보다 낮을 가능성이 큰 중증 환자를 대상으로 하여 보다 장기간의 처치가 주상골 높이에 미치는 영향을 규명하는 후속 연구가 요청된다.

\section{통증의 변화}

무지외반증 환자의 보존적 치료를 목적으로 정형외과 적 보조기와 인솔, 신발을 사용하는 교정 방법의 주목적 은 벌어진 엄지발가락을 안쪽으로 모으는 것이었다 (Sammarco \& Nichols, 2005). 그러나 이와 같은 보조 기는 발의 정상적인 활동성을 감소시켰고, 장시간 착용 시 무지외반증에 의한 통증에 더해 딱딱한 보조기와 닿는 다른 신체 부위의 통증이 추가적으로 발생하는 문제가 계 속 보고되었다(Hawke et al. 2008).

따라서 무지외반증 환자에게 CKT처치를 적용하는 방 법이 정형외과적 보조기를 사용하는 대안으로 제시되었 다. Jeon et al.(2004)은 무지외반증 환자를 대상으로 4 주간에 걸쳐 CKT처치를 적용한 결과 무지외반 각도가 유의하게 감소되었고, 동시에 시각적 통증 척도가 유의하 게 감소되었다고 보고하였다. 이 연구에서도 처치 전과 비교하여 $\mathrm{CKT}$ 처치 후 시각적 통증 척도가 유의하게 감 소되었고, $\mathrm{CEX}+\mathrm{CKT}$ 처치에서 유의하게 감소되었다. 그러나 $\mathrm{CEX}$ 처치에서는 시각적 통증 척도의 유의한 변화 가 나타나지 않았다.

무지외반증 환자에게 있어서 교정운동은 감소된 장무 지굴근과 단무지굴근의 근력 향상과 힘줄의 탄성 회복을 위하여 반드시 필요하다(Chopra et al., 2015). 그러나 발의 통증이 있는 상태에서 실시하는 교정운동은 통증을 회피하기 위하여 중족부 외측으로 체중을 이동시킬 가능
성을 증가시켜 부정적인 결과를 초래한다(Wen et al., 2012). 따라서 무지외반증 환자에게 통증 감소 목적으로 교정운동을 단독 처치하는 것은 적절하지 못 한 것으로 판단된다.

한편, Karabicak et al.(2015)은 무지외반증 환자를 대상으로 10 일간 CKT처치와 함께 발가락의 외전근과 굴 곡근 운동을 복합 처치한 결과 무지외반 각도가 감소되고 통증 지수가 7.5 에서 1.1 로 감소되었다고 보고하여 이 연 구의 $\mathrm{CEX}+\mathrm{CKT}$ 처치에서 얻은 결과와 일치하였다. 복 합 처치의 경우 무지외반증 환자의 통증이 개선된 것은 주로 CKT처치에 의한 것이라고 판단되며, 따라서 무지 외반증 환자의 치료를 위한 초기 단계에서 통증을 우선적 으로 완화시키기 위해서는 CKT처치를 적극적으로 적용 할 필요가 있다고 판단된다.

\section{결 론}

이 연구에서 20 30대 여성 중등도 무지외반증 환자 를 대상으로 일회성 교정운동과 교정테이핑이 보행패턴, 족저압, 평형성, 그리고 통증에 미치는 영향을 규명하고 자 하였으며, 이 연구의 주요 결과는 다음과 같다.

보행 패턴과 관련하여, $\mathrm{CEX}$ 처치와 $\mathrm{CEX}+\mathrm{CKT}$ 처치에 서 보폭과 입각기 발의 앞, 뒤 길이가 유의하게 증가되었 다. 보행 주기와 관련하여, $\mathrm{CEX}$ 처치와 $\mathrm{CEX}+\mathrm{CKT}$ 처치 에서 전족부, 중족부, 그리고 뒤꿈치의 접촉 시간이 유의 하게 감소되었고, $\mathrm{CEX}$ 처치에서 양 하지 지지기가 유의 하게 감소되었으며, $\mathrm{CEX}+\mathrm{CKT}$ 처치보다 $\mathrm{CEX}$ 처치가 더 효과적인 것으로 나타났다. 보행 시 족저압과 관련하여, $\mathrm{CEX}+\mathrm{CKT}$ 처치에서 중족부와 뒤꿈치 최대압력이 유의 하게 증가되었고, $\mathrm{CEX}$ 처치에서 전족부 최대압력이 유의 하게 증가되었다. 평형성과 관련하여, $\mathrm{CEX}$ 처치와 $\mathrm{CKT}$ 처치에서 눈감고외발서기가 유의하게 증가되었다. 통증 과 관련하여, $\mathrm{CKT}$ 처치와 $\mathrm{CEX}+\mathrm{CKT}$ 처치에서 통증 척 도가 유의하게 감소되었다.

이상에서 기술한 결과를 종합하면, 중등도 무지외반증 을 가진 20 30대 여성의 보행 패턴, 보행 주기, 그리고 보행 시 족저압이 일회성 $\mathrm{CEX}$ 처치만으로도 유의하게 개 선되어 추가적인 $\mathrm{CKT}$ 처치가 불필요하며, 평형성과 통증 
은 일회성 CKT처치만으로도 유의하게 개선되었다고 결 론지을 수 있다. 이 연구의 결과에 근거하여 운동 경험이 없으며 무지외반증으로 인하여 통증이 있는 20 30대 여 성 중등도 무지외반증 환자의 경우 통증 감소와 평형성 개선을 위하여 우선적으로 $\mathrm{CKT}$ 처치를 한 후, 통증이 감 소되면 보행 매개변수의 개선을 위하여 $\mathrm{CEX}$ 처치를 하는 단계적 적용이 필요할 것으로 판단된다. 향후 이 주제와 관련하여 보다 장기간의 처치 효과를 종단적으로 규명하 는 후속 연구가 요청된다.

\section{참고문헌}

Ahn, C. S. \& Jung. S. (2001). Astudy on gait analysis of normal 20' adult male and female. Journal of Korean Physical Therapy Science, 8(2), 961-965.

Barkoukis, V., Sykaras, E., Costa, F., \& Tsorbatzoudis, H. (2002). Effectiveness of taping and bracing in balance. Perceptual and Motor Skills, 94(2), 566-574.

Bayar, B., Erel, S., Simsek, İ. E., Sumer, E., \& Bayar, K. (2011). The effects of taping and foot exercises on patients with hallux valgus: a preliminary study. Turkish Journal of Medical Sciences, 41(3), 403-409.

Benvenuti, F., Ferrucci, L., Guralnik, J. M., Gangemi, S., \& Baroni, A. (1995). Foot pain and disability in older persons: An epidemiologic survey. Journal of the American Geriatrics Society, 43(5), 479-484.

Choi, Y. J. \& Seo, H. K. (2016). Immediate effects of ankle kinesiotaping on pain, foot pressure distribution and balance in patient with chronic ankle instability. Journal of Korean Society for Rhythmic Exercises, 9(2), 37-46.

Chopra, S., Moerenhout, K., \& Crevoisier, X. (2015). Characterization of gait in female patients with moderate to severe hallux valgus deformity. Clinical Biomechanics, 30(6), 629-635.

Clark, M., \& Lucett, S. (2010). NASM essentials of corrective exercise training. Lippincott Williams \& Wilkins.

Coughlin, M. J. \& Jones, C. P. (2007). Hallux valgus: Demographics, etiology, and radiographic assessment. Foot and Ankle International, 28(7), 759-777.

Deenik, A. R., de Visser, E., Louwerens, J. K., de Waal Malefijt, M., Draijer, F. F., \& de Bie, R. A. (2008). Hallux valgus angle as main predictor for correction of hallux valgus. BMC Musculoskeletal Disorders, 9(70), doi.org/10.1186/1471-24749-70.

Edwards, W. T. (2007). Effect of joint stiffness on standing stability. Gait and Posture, 25(3), 432-439.

Ferrari, J., Higgins, J. P., \& Prior, T. D. (2004). Interventions for treating hallux valgus and bunions. Cochrane Database of Systematic Reviews, 1, 1465-1858.

Filardi, V. (2019). Hallux valgus (HV): A multi-approach investigation analysis. Journal of Orthopedics. doi.org/10.1016/ j.jor.2019.09.014.

Franz, J. R., Maletis, M., \& Kram, R. (2014). Real-time feedback enhances forward propulsion during walking in old adults. Clinical Biomechanics, 29(1), 68-74.

Grieve, R., Goodwin, F., Alfaki, M., Bourton, A. J., Jeffries, C., \& Scott, H. (2015). The immediate effect of bilateral self myofascial release on the plantar surface of the feet on hamstring and lumbar spine flexibility: A pilot randomised controlled trial. Journal of Bodywork \& Movement therapies, 19(3), 544-552.

Gur, G., Ozkal, O., Dilek, B., Aksoy, S., Bek, N., \& Yakut, Y. (2017). Effects of corrective taping on balance and gait in patients with hallux valgus. Foot and Ankle International, 38(5), 532-540.

Hawke, F., Burns, J., Radford, J. A., \& Du Toit, V. (2008). Custom made foot orthoses for the treatment of foot pain. Cochrane Database of Systematic Reviews, 3, doi:10.1002/14651858. CD006801.pub2.

Heit, E. J., Lephart, S. M., \& Rozzi, S. L. (1996). The effect of ankle bracing and taping on joint position sense in the stable ankle. Journal of Sport Rehabilitation, 5(3), 206-213.

Health Insurance Review \& Assessment Service(2015). Healthcare Bigdata Hub, Health Statistical Information.

Jafari, M., Zolaktaf, V., \& Ghasemi, G. (2019). Functional movement screen composite scores in firefighters: Effects of corrective exercise training. Journal of Sport Rehabilitation, 1(aop), 1-5.

Jeon, M. Y., Jeong, H. C., Jeong, M. S., Lee, Y. J., Kim, J. O., Lee, S. T., \& Lim, N. Y. (2004). Effects of taping therapy on the deformed angle of the foot and pain in hallux valgus patients. Journal of Korean Academy of Nursing, 34(5), 685-692.

Kalron, A. \& Achiron, A. (2013). Postural control, falls and fear of falling in people with multiple sclerosis without mobility aids. 
Journal of The Neurological Sciences, 335(1-2), 186-190.

Karabicak, G. O., Bek, N., \& Tiftikci, U. (2015). Short-term effects of kinesiotaping on pain and joint alignment in conservative treatment of hallux valgus. Journal of Manipulative and Physiological Therapeutics, 38(8), 564-571.

Kim, K. T., Kwon, K. S., Kim. K. T., \& Lee, K. G. (2014). The effects of transformation on static balance and physical fitness of foot type. The Korean Journal of Physical Education, 23(6), 1139-1148.

King, D. M. \& Toolan, B. C. (2004). Associated deformities and hyper mobility in hallux valgus: an investigation with weight bearing radiographs. Foot and Ankle International, 25(4), 251-255.

Konradsen, L., Voigt, M., \& Hojsgaard, C. (1997). Ankle inversion injuries: the role of the dynamic defense mechanism. The American Journal of Sports Medicine, 25(1), 54-58.

Kosiki, K., Luukinen, H., Laippala, P., \& Kivela, S. L. (1996). Physiological factors and medications as predictors of injurious falls by elderly people: A prospective population-based study. Age and Ageing, 25(1), 29-38.

Lee, H. S., Kim, E. J., Park, I. S., Bae, M. S., Shin, J. W., Lee, J. U., Jang, Y. Y., Jo, H. J., Choi, K. N., Choi, H. R., \& Kim, J. S. (2015). The effects of combined exercises of elastic-band and short foot exercise on plantar foot pressure, toe angle and balance for patients with low to moderate hallux valgus. Journal of the Korean Society of Integrative Medicine, 3(3), 73-88.

Luca, C. C., Nadayil, G., Dong, C., Nahab, F. B., Field-Fote, E., \& Singer, C. (2017). Dalfampridine in Parkinson's disease related gait dysfunction: A randomized double blind trial. Journal of The Neurological Sciences, 379, 7-11.

Lynn, S. K., Padilla, R. A., \& Tsang, K. K. (2012). Differences in static-and dynamic-balance task performance after 4 weeks of intrinsic-foot-muscle training: The short-foot exercise versus the towel-curl exercise. Journal of Sport Rehabilitation, 21(4), 327-333.

Martínez-Gramage, J., Merino-Ramirez, M. A., Amer-Cuenca, J. J., \& Lisón, J. F. (2016). Effect of Kinesio Taping on gastrocnemius activity and ankle range of movement during gait in healthy adults: a randomized controlled trial. Physical Therapy in Sport, 18, 56-61.

Menz, H. B., Morris, M. E., \& Lord, S. R. (2005). Foot and ankle characteristics associated with impaired balance and functional ability in older people. The Journals of Gerontology Series A: Biological Sciences and Medical Sciences, 60(12), 1546-1552.

Moerenhout, K., Chopra, S., \& Crevoisier, X. (2019). Outcome of the modified Lapidus procedure for hallux valgus deformity during the first year following surgery: A prospective clinical and gait analysis study. Clinical Biomechanics, 61, 205-210.

Nix, S., Smith, M., \& Vicenzino, B. (2010). Prevalence of hallux valgus in the general population: A systematic review and meta-analysis. Journal of Foot and Ankle Research, 3(1), 1757-1146-3-21.

Nüesch, C., Overberg, J. A., Schwameder, H., Pagenstert, G., \& Mündermann, A. (2018). Repeatability of spatiotemporal, plantar pressure and force parameters during treadmill walking and running. Gait and Posture, 62, 117-123.

Park, S. H. \& Kim, J. T. (2002). Biomechanics: Analysis about adult female gait pattern based on the body mass index. The Korean Journal of Physical Education, 41(2), 743-752.

Park, S. J., Ko, B. G., SongHong-sun, Song, J. H., Lee,M. I., Jae, S. Y., Jeon, J. Y., Kwon, J. P., Lee, J. Y., \& Park, S. H. (2018). Development of criterion referenced health fitness standards for chronic disease prevention in Korean adults: The Korea Institute of Sport Science Fitness Standards Study (KISS FitS). The Korean Journal of Physical Education, 57(6), 235-247.

Payandeh, M., Khoshraftar, Y. N., Ebrahimi, A. A., \& Damavandi, M. (2014). Effect of corrective exercise program on the ground reaction force in student with flat foot during gait cycle. Journal of Research in Rehabilitation Sciences, 10(2), 292-305.

Pérez-Soriano, P., Lucas-Cuevas, A. G., Aparicio-Aparicio, I., \& Llana-Belloch, S. (2014). Effects of kinesiotape taping on plantar pressure and impact acceleration during walking. Science and Sports, 29(5), 282-287.

Richards, R., van den Noort, J. C., van der Esch, M., Booij, M. J., \& Harlaar, J. (2018). Gait retraining using real-time feedback in patients with medial knee osteoarthritis: Feasibility and effects of a six-week gait training program. The Knee, 25(5), 814-824.

Sammarco, V. J. \& Nichols, R. (2005). Orthotic management for disorders of the hallux. Foot and Ankle Clinics, 10(1), 191-209.

Schuh, R., Hofstaetter, S. G., Adams Jr, S. B., Pichler, F., Kristen, K. H., \& Trnka, H. J. (2009). Rehabilitation after hallux valgus surgery: importance of physical therapy to restore weight 
bearing of the first ray during the stance phase. Physical Therapy, 89(9), 934-945.

Segal, N. A., Glass, N. A., Teran-Yengle, P., Singh, B., Wallace, R. B., \& Yack, H. J. (2015). Intensive gait training for older adults with symptomatic knee osteoarthritis. American Journal of Physical Medicine and Rehabilitation/Association of Academic Physiatrists, doi:10.1097/PHM.0000000000000264.

Shamus, J., Shamus, E., Gugel, R. N., Brucker, B. S., \& Skaruppa, C. (2004). The effect of sesamoid mobilization, flexor hallucis strengthening, and gait training on reducing pain and restoring function in individuals with hallux limitus: a clinical trial. Journal of Orthopaedic \& Sports Physical Therapy, 34(7), 368-376.

Shih, K. S., Chien, H. L., Lu, T. W., Chang, C. F., \& Kuo, C. C. (2014). Gait changes in individuals with bilateral hallux valgus reduce first metatarsophalangeal loading but increase knee abductor moments. Gait and Posture, 40(1), 38-42.

Trnka, H. J., Krenn, S., \& Schuh, R. (2013). Minimally invasive hallux valgus surgery: A critical review of the evidence. International Orthopaedics, 37, 1731 - 1735.

Vanore, J. V., Christensen, J. C., Kravitz, S. R., Schuberth, J. M.,
Thomas, J. L., Weil, L. S., Zlotoff, H. J. \& Couture, S. D. (2003). Diagnosis and treatment of first metatarsophalangeal joint disorders. Section 2: hallux rigidus. The Journal of Foot and Ankle Surgery, 42(3), 124-136.

Webster, K. A. \& Gribble, P. A. (2013). A comparison of electromyography of gluteus medius and maximus in subjects with and without chronic ankle instability during two functional exercises. Physical Therapy in Sport, 14(1), 17-22.

Wen, J., Ding, Q., Yu, Z., Sun, W., Wang, Q., \& Wei, K. (2012). Adaptive changes of foot pressure in hallux valgus patients. Gait and Posture, 36(3), 344-349.

Williams, D. S. \& McClay, I. S. (2000). Measurements used to characterize the foot and the medial longitudinal arch: Reliability and validity. Physical Therapy, 80(9), 864-871.

Yoo, S. D., Kim, H. S., Lee, J. H., Yun, D. H., Kim, D. H., Chon, J., Lee, S. A., Han. Y. J., Soh. y. s., Kim. Y., Han. S. Y., Lee. W. J., \& Han. Y. R. (2017). Biomechanical parameters in plantar fasciitis measured by gait analysis system with pressure sensor. Annals of Rehabilitation Medicine, 41(6), 979-989. 


\title{
일회성 교정운동과 테이핑 처치가 여성 중등도 무지외반증 환자의 보행 패턴, 족저압, 평형성 및 통증에 미치는 영향
}

\author{
유태근 ${ }^{1}$, 조현석 ${ }^{2}$, 이만균 $^{3}$ \\ 1경희대학교 대학원생 \\ 2경희대학교 연구원 \\ 3경희대학교 교수
}

〔목적〕 보행 시 첫 번째 중족지절관절에 통증이 있는 중등도(2단계)의 무지외반증 환자를 대상으로 보존적 치료 목적의 교정운동과 교정테이핑의 일회성 단일처치 및 복합처치가 보행 패턴, 족저압, 평형성, 그리고 통 증에 미치는 영향을 규명하고자 하였다.〔방법〕 연령이 20 30대인 여성 중 무지외반증 환자 21명(연령 $30.1 \pm 5.1$ 세, 신장 $164.1 \pm 4.8 \mathrm{~cm}$, 체중 $56.7 \pm 6.8 \mathrm{~kg}$, 체질량지수 $21.2 \pm 5.7 \mathrm{~kg} \cdot \mathrm{m}^{-2}$, 무지외반 각도 $\left.27.2 \pm 6.1^{\circ}\right)$ 을 연구의 대상자로 선정하여, 각각 교정운동처치, 교정테이핑처치, 그리고 교정운동과 교정테이 핑의 복합처치에 counterbalanced order에 따라 반복적으로 참여하도록 하였다. 전의 처치가 다음 처치에 미치는 영향을 최소화하기 위하여 처치 간에 1 주일의 wash-out 기간을 두었다. 각 처치 중 보행 패턴, 족저 압, 평형성, 그리고 통증과 관련된 변인을 측정하였다. 세 처치 간, 그리고 시기 간 종속변인의 차이를 동시에 분석하기 위하여 반복 이원변량 분석(repeated two-way ANOVA)을 실시하였다. (결과) 이 연구에서 얻은 주요 결과는 다음과 같다. 1) 보행 패턴과 관련하여, 교정운동처치 및 교정운동과 교정테이핑의 복합처치에서 보폭, 입각기 발의 앞, 뒤 길이가 유의하게 증가되었고, 걸음 수가 유의하게 감소되었다. 2) 보행 주기와 관련 하여, 교정운동처치 및 교정운동과 교정테이핑의 복합처치에서 전족부 접촉 시간, 중족부 접촉 시간, 그리고 뒤꿈치 접촉 시간이 유의하게 감소되었고, 교정운동처치에서 양 하지 지지기가 유의하게 감소되었다. 3) 보행 시 족저압과 관련하여, 교정운동과 교정테이핑의 복합처치에서 중족부 최대압력과 뒤꿈치 최대압력이 유의하 게 증가되었고, 교정운동처치에서 전족부 최대압력이 유의하게 증가되었다. 4) 평형성과 관련하여, 교정운동 처치와 교정테이핑처치에서 눈감고외발서기가 유의하게 증가되었다. 5) 통증과 관련하여, 교정테이핑처치와 및 교정운동과 교정테이핑의 복합처치에서 통증 지수가 유의하게 감소되었다. 〔결론) 이상에서 기술한 결과를 종합하면, 중등도 무지외반증을 가진 20 30대 여성의 보행 시 전족부의 통증을 감소시키기 위하여 일회성 교정테이핑처치가 효과적이고, 족저압, 보행 패턴, 보행 주기, 그리고 평형성의 경우 일회성 교정운동처치를 통하여 충분하게 개선되었다고 결론지을 수 있다. 따라서 운동 경험이 없는 중등도 무지외반증을 가진 20 30 대 여성을 대상으로 교정 초기에 교정테이핑 처치를 통하여 통증을 감소시키고, 추후 교정운동처치를 통하여 보행 패턴, 보행 주기, 보행시 족저압, 그리고 평형성을 개선시키는 처치의 단계적 적용이 필요할 것이라고 판단된다. 향후 이 주제와 관련하여 장기간의 처치 효과를 규명하는 후속 연구가 요청된다.

주요어: 교정운동, 탄성 테이프, 무지외반증, 보행 패턴, 족저압 